Огляди літератури, оригінальні дослідження, погляд на проблему, ювілеї

УДК 616.44-02-091-092

DOI 10.11603/1811-2471.2018.v0.i2.8903

\title{
ДО СТРУКТУРНИХ ТА ФУНКЦІОНАЛЬНИХ ПЕРЕДУМОВ ВИНИКНЕННЯ ТИРЕОЇДНОї ПАТОЛОГІї (ОГЛЯД ЛІТЕРАТУРИ)
}

๑о. І. Рябуха

\section{Львівський медичний інститут}

РЕЗЮМЕ. Значне поширення та суспільне значення тиреоїдної патології робить необхідним поглиблене з'ясування основних передумов її виникнення.

Мета роботи - проаналізувати та узагальнити особливості будови і функціонування щитоподібної залози, які можуть бути передумовами виникнення ії̈ патології. Умовно їх можна поділити на структурні та функціональні. Складний ембріогенез щитоподібної залози, значна варіабельність ії макроморфологічних типів, рясна васкуляризація та особливості вегетативної іннервації, наявність у паренхімі органа, поряд із тироцитами, їх клітин-антагоністів, а також клітин-продуцентів інших біологічно активних речовин, та клітин, які беруть участь у імунних процесах, є основними морфологічними передумовами появи і розвитку девіацій у діяльності залози. Разом з тим, регулювання функції щитоподібної залози здійснюється розгалуженою системою екстратиреоїдних та інтратиреоїдних зв'язків, з яких найбільше значення мають зв'язки гіпоталамо-гіпофізарної, вегетативної нервової та імунної систем, діяльність С-клітин, концентрація іонів йоду та кальцію в сироватці крові. Така складна система контролю, попри свою поліваріантність, може бути вразливою у разі змін умов існування, відхилень чи порушень у діяльності органа. Вплив регулювальної системи гіпоталамус-гіпофіз на щитоподібну залозу відбувається залежно від кількості йоду, що надходить до організму. Споживання незначних доз йоду супроводжується зміною низки функціональних констант, зокрема інтратиреоїдних співвідношень між монойодтирозином та дийодтирозином, дийодтирозином та тироксином, трийодтирозином та тироксином; у випадках вираженого дефіциту йодуу тканинах зростає швидкість трансформації ${ }_{4}$ в $\mathrm{T}_{3}$ та значно зменшується рівень $\mathrm{T}_{4}$ при нормальному або збільшеному вмісті $\mathrm{T}_{3}$, що може призвести до вичерпання адаптаційних резервів організму. Тривале споживання збільшеної кількості йоду і зумовлене цим підвищення рівня ТТГ порушує координування діяльності щитоподібної залози і функціонально пов'язаних з нею органів.

КЛючОВІ СЛОВА: щитоподібна залоза; особливості будови; особливості функціонування.

Вступ. Кількісне зростання тиреоїдної патології та зміна її основних нозологічних форм, що спостерігається в Україні впродовж останніх років, зумовлені переважно впливом таких антропогенних чинників як промислове та радіаційне забруднення. Окрім того, значна частина населення України проживає в йододефіцитних регіонах, що суттєво обтяжує перебіг захворювань щитоподібної залози $[6,8,14,15]$. 3 огляду на це, визначення і характеристика чинників, що призводять до порушення діяльності ЩЗ, становлять значний інтерес.

Основні передумови виникнення тиреоїдної патології можна умовно поділити на дві групи. До першої належать особливості будови органа, до другої - особливості його діяльності в умовах, які іï не порушують (умови норми) або в умовах її порушення, наприклад споживання зміненої (зменшеної/збільшеної) кількості йоду.

Щитоподібна залоза (ЩЗ) - найбільша з усіх залоз внутрішньої секреції. У нормі їі маса коливається в межах 15-20 г [15]; залежно від біогеохімічного ареалу проживання ці значення можуть змінюватися і сягати більших величин [27, 32].

Специфічна діяльність щ3, точніше її зачатка, яка визначається здатністю до поглинання радіоізотопів йоду, починається доволі рано. Уже на 3 тижні внутрішньоутробного життя поряд із за- чатком серця виявляють зачаток щ3 [38]; достатньою мірою він розвивається на 12 тижні. Морфологічно зачаток залози складається із двох частин - медіальної та латеральної. Аномалії розвитку стосуються переважно медіального зачатка: прижиттєво найчастіше діагностують його недорозвиненість та атипове розташування; деякі автори девіації ембріональних зачатків щЗ розглядають як осередки імовірного формування пухлинних процесів [43]. На складному ембріогенезі Щ3 і пов'язаній з цим великій кількості вроджених патологій органа наголошено у фундаментальному керівництві з оперативної хірургії, виданому за редакцією І. Літтманна [13].

Форма залози дорослої людини підковоподібна. Зазвичай щз має дві, неоднакові за розмірами, бічні частки - праву і ліву, які з'єднані між собою перешийком. Окрім типової будови щз може мати і макроморфологічні варіанти. У короткому курсі оперативної хірургії з топографічною анатомією, виданому за редакцією В. Шевкуненка 1947 року, їх зображено одинадцять. Найчастіше трапляються відсутність перешийка або наявність додаткових часток, з яких найбільше значення має пірамідальна частка, яка відходить від перешийка або лівої частки залози вгору до щитоподібної вирізки або тіла під'язикової кістки; 
Огляди літератури, оригінальні дослідження, погляд на проблему, ювілеї

існують й інші варіанти атипової будови щитоподібної залози - асиметрія часток або ж відсутність однієї з них.

ЩЗ рясно васкуляризована [13]. Усередині залози артеріоли інтенсивно розгалужуються, оточуючи кожний фолікул капілярними сплетеннями. Хоча маса залози не перевищує 0,4 \% маси тіла, на неї припадає 2 \% загального плину крові; при захворюваннях плин крові через орган може зростати до 100 разів [37]. Тонкостінні капіляри відділені від тироцитів фолікулів тільки базальною мембраною. Сітка лімфатичних судин у залозі досить розвинута і розгалужена. У переважній більшості випадків лімфатичні судини супроводжують артерії і впадають у трахеальні, глибокі шийні та середостінні лімфатичні вузли.

Іннервація ЩЗ реалізується за посередництвом вегетативної нервової системи. Парасимпатичні волокна ЩЗ отримує від шийної частини блукаючого нерва. Симпатичні волокна, які формують щитоподібні нерви, відходять від вузлів шийного симпатичного стовбура, причому ці адренергічні волокна розташовані не тільки навколо судин, але й безпосередньо контактують із клітинами фолікулярного епітелію. Катехоламіни, які виділяються із нервових закінчень симпатичної нервової системи, відіграють певну роль у секреторних реакціях ЩЗ, зокрема впливають на її функцію як опосередковано через швидкість плину крові, так і безпосередньо діючи на тироцит. Так, зокрема, дослідженнями [45] виявлено, що у щурів симпатична активність корелює з функціональною активністю і розмірами щз. Окрім того, оскільки іннервація щЗ $є$ переважно периваскулярною, подразнення будь-якого з їі нервів супроводжується негайною зміною інтенсивності кровообігу в залозі [34].

Структурною одиницею ЩЗ $\epsilon$ фолікул - міхурець, заповнений колоїдом, що $є$ гомогенною білковою субстанцією. Стінка фолікула утворена одношаровим епітелієм, висота клітин якого зумовлюється ступенем функціональної активності органа [10]. Фолікулярний тироцит має виражену полярність. Його апікальна частина безпосередньо контактує з інтрафолікулярним колоїдом, базальна частина щільно прилягає до перикапілярного простору.

У паренхімі залози розрізняють кілька типів клітин. Основну масу органа сформовано з клітин типу A, які $\epsilon$ продуцентами тиреоїдних гормонів. Оскільки саме з них утворені стінки тиреоїдних фолікулів, А-клітини отримали назву фолікулярних тироцитів, або фолікулярного епітелію. Кожен фолікул оплетений густою сіткою капілярів. Цілковитій реалізації специфічної функції тироцита сприяє його полярна організація.
В-клітини (клітини Ашкеназі-Гюртле, еозинофільні клітини, паренхіматозні клітини, мікротироцити, онкоцити) за розмірами є більшими, ніж тироцити, мають овальну або видовжену форму, позбавлені полярності. У їх цитоплазмі виявлено велику кількість мітохондрій та еозинофільних гранул, підвищений вміст фосфоліпідів, холестерину, амінокислот. Висока активність окисно-відновних ферментів та біогенних амінів, зокрема серотоніну, дає змогу віднести В-клітини до нейроендокринних клітин [3]. Збільшену кількість В-клітин виявляють у зоні гіперпластичних, запальних, автоімунних процесів [18]; вони можуть бути осередком розвитку аденом, які мають схильність до малігнізації.

Ще одним типом клітин $\epsilon$ С-клітини, вміст яких у залозі дорослих людей сягає більше ніж 1 \% загальної клітинної популяції [32]. В інтерфолікулярних острівцях С-клітини скупчуються групами або розташовуються поодинці між клітинами фолікулярного епітелію. Характерною особливістю С-клітин $\epsilon$ розміщення біля капілярів і відсутність безпосереднього контакту з інтрафолікулярним колоїдом. С-клітини не можуть поглинати йод, тому вони не синтезують йодовмісних гормонів, натомість виробляють їх антагоніст - тиреокальцитонін (кальцитонін), а також серотонін, соматостатин. Усталилася думка, що С-клітини мають структурну і функціональну автономію $[1,9]$. Так, зокрема, вони беруть участь у перебігу процесів відновлення у щЗ після ії резекції [9]. Вважають, що саме скупчення С-клітин може стати осередком виникнення медулярного раку органа [37]. Функціональна активність С-клітин значною мірою зумовлює морфофункціональний стан тироцитів [17]: кальцитонін перикринним шляхом впливає на тироцити і викликає їхню проліферацію [12], а соматостатин має здатність активізувати автоімунні процеси [5]. Існують припущення, що у хворих на дифузний токсичний зоб автоімунну реакцію зумовлює високий рівень продукованого С-клітинами соматостатину, а сама реакція $\epsilon$ своєрідним захистом, спрямованим на нейтралізацію надлишкової кількості гормону [5]. Таким чином, С-клітини $\epsilon$ важливим фактором регулювання діяльності ЩЗ. Вважають, що збільшення синтезу кальцитоцину потенціює функціональну активність щ3, проте підвищений рівень соматостатину не тільки стимулює активність імунних процесів на органному рівні, а й знижує синтетичну активність тироцитів.

Необхідно вказати, що в інтерстиціальному просторі щЗ виявлено дендритичні клітини, які належать до головного комплексу гістосумісності і беруть участь у перебігу імунних процесів $[11,35]$.

Структура ЩЗ доволі складна. Це дає підставу розглядати можливість виокремлення певних 
Огляди літератури, оригінальні дослідження, погляд на проблему, ювілеї

морфологічних типів її паренхіми. Врахування типологічних особливостей паренхіми органа (структури, форми і розмірів фолікулів, ступеня щільності інтрафолікулярного колоїду, кількості та активності С-клітин) дає змогу оптимізувати хірургічне лікування пацієнтів, зокрема з дифузним токсичним зобом - поліпшити їх передопераційне підготування, обрати доцільну тактику резекції, зменшити ризик післяопераційних рецидивів [4].

Основним фізіологічним регулятором функції щитоподібної залози є гіпоталамо-гіпофізарна система $[1,36,39,40]$. Провідну роль у ній відіграють тиреотропін-рилізинг-гормон (ТРГ), який синтезується гіпоталамусом, та тиреотропний гормон гіпофіза (ТТГ): ТРГ спричиняє синтез ТТГ, водночас синтез ТРГ зумовлюється рівнем тиреоїдних гормонів у крові. ТТГ взаємодіє з тироцитами і впливає на щЗ через аденілатциклазну систему. Окрім того, ТТГ впливає на перебіг трофічних процесів і на всі фази біосинтезу гормонів щз. Вплив ТТГ на залозу регулюється за принципом зворотного зв'язку: надмірна секреція ТТГ пригнічує її функцію, тоді як помірний вміст ТТГ у сироватці крові призводить до активізування гормонопоезу в Щ3 [28]. Оскільки регулювання діяльності ЩЗ та інших залоз внутрішньої секреції реалізується системою гіпофіз-гіпоталамус, між ендокринними органами наявний взаємовплив. Зокрема, наявність рецепторів до інсуліну в культурі клітин ЩЗ розширює попередні уявлення щодо їі чутливості до цього гормону [44]. Тироцити мають рецептори до андрогенів та естрогенів [41]. Встановлено, що проліферації фолікулярних клітин сприяють естрадіол та ендогенні метаболіти естрогенів [29, 30].

Окрім тироцитів, рецептори до ТТГ мають і С-клітини, що дає змогу впливати на щЗ через зміни рівнів інших гормонів. Про значний вплив гіпофіза на щЗ свідчить і коливання ії теплового балансу в жінок фертильного віку впродовж оваріально-менструального циклу, найнижчі показники якого зареєструють під час менструальної фази, а найвищі - під час овуляції [21].

Механізм гіпоталамо-гіпофізарного регулювання функції щз значною мірою залежить від впливу інших регулювальних систем. Так, реалізація тиреоїдної функції зумовлена низкою позагіпофізарних механізмів - гемодинамічних, нервових, мінеральних, імунологічних [2]. Зокрема, гормонопоез у ЩЗ може стимулювати прискорення інтратиреоїдного кровообігу. Водночас швидкість та об'єм інтраорганного плину крові значною мірою залежать від стану нервової системи, а саме від її вегетативного відділу [20].

В експериментах in vitro було показано, що катехоламіни стимулюють органіфікацію йоду в
щЗ та інгібують ТТГ-залежну секрецію її гормонів [25]. Установлено, що вміст катехоламінів (епінефрину, норепінефрину, дофаміну) у гіпоталамусі пов'язаний з рівнем тиреоїдних гормонів: при гіпертиреозі спостерігається зменшення концентрації дофаміну [19].

Стимулювання адренергічних нервових закінчень та дія катехоламінів посилюють процеси ендоцитозу тиреоглобуліну у фолікулярних тироцитах та міграцію лізосомальних тілець до апікальних мембран, що сприяє посиленню секреції гормонів щ3. Катехоламіни збільшують концентрацію цАМФ, поглинання йодиду тироцитами, синтез тиреоїдних гормонів. Стимулювальний вплив катехоламінів та ТТГ на функцію ЩЗ початково здійснюється на мембранні рецептори тироцита, пізніше реалізується через внутрішньоклітинні процеси - активізацію аденілатциклази і збільшення утворення цАМФ. Установлено, що речовини-антагоністи $\beta$-адренорецепторів зумовлюють збільшення рівня цАМФ, утворення колоїдних крапель, секрецію тиреоїдних гормонів, тоді як антагоністи а-адренергічних речовин інгібують утворення цАМФ [24].

Ацетилхолін і такі холіноміметики як пілокарпін та езерин in vitro пригнічують функціональну активність тканини щЗ навіть після попередньої її стимуляції ТТГ [33]. Проте in vivo підвищення парасимпатичної (холінергічної) активності нервової системи призводить до зниження секреторних можливостей органа. Зміни функціональної активності залози супроводжуються змінами вмісту ацетилхоліну та ацетилхолінестерази. Дослідженнями І. І. Шестітко [22] встановлено, що при струмі підвищується тонус парасимпатичної нервової системи. Існує також думка про переважно симпатичну регуляцію тиреоїдної секреції та про участь симпатичної нервової системи у виникненні деяких гіпертиреозів [45]. На її користь можуть свідчити й дані клінічної практики, коли для зменшення клінічних проявів гіпертиреозу рекомендують вживати адреноблокатори [24].

Певний вплив на тиреоїдну функцію має і гістамін. Вважають, що він бере участь у регулюванні інтратиреоїдного плину крові та специфічній діяльності клітин фолікулярного епітелію [2]. Загальна тенденція до зниження тканинної концентрації гістаміну на тлі гіпертиреоїдизації може бути зумовлена надмірним продукуванням глюкокортикоїдів, яке спостерігається в таких випадках подальшим прискоренням тканинного метаболізму гістаміну та зменшенням його концентрації [16].

Роль оксиду азоту (NO) у процесах регулювання тиреоїдної функції потребує поглибленого вивчення. R. L. Singhal et al. [42] спостерігали під- 
Огляди літератури, оригінальні дослідження, погляд на проблему, ювілеї

вищення активності L-аргінін-NO-синтази (NOS) у паравентрикулярних та супраоптичних ядрах гіпоталамуса при гіпертиреозі та її зменшення при гіпотиреозі. На думку авторів, оксид азоту впливає на регуляцію гіпоталамічного портального плину крові, що зумовлює вивільнення ТРГ. Зниження скоротливої реакції аорти на норадреналін при гіпертиреозі, ймовірно, пов'язане з посиленням продукування NO клітинами ендотелію [7].

Аномальні стимулятори тиреопоезу, які належать до групи імуноглобулінів, виявлено у сироватці хворих на гіпертиреоз. Можна припустити, що імунологічні реакції $\epsilon$ відповіддю на пошкодження клітин щз і потрапляння у кров інтрацелюлярних тиреоїдних протеїнів. Із сироватки крові пацієнтів з хворобою Грейвса-Базедова виділено імуноглобулін, який зв'язує ТТГ. Вважають, що ці імуноглобуліни не тільки мають рецептори для зв'язування ТТГ, але й самі здійснюють тиреостимулювальний вплив.

Попри те, що щЗ $є$ саморегулювальною системою, їі функціонування детерміновано надходженням в організм із зовнішнього середовища йодовмісних сполук, що робить ії̈ залежною від умов довкілля. Йод у земній корі міститься вкрай нерівномірно: регіони з його низьким вмістом реєструються в усіх куточках Землі. Така мозаїчність йодної мапи зумовила появу і розвиток процесів, які дають змогу організму пристосовуватися до дефіциту цього есенціально важливого мікроелемента.

Дефіцит йоду $\epsilon$ пусковим чинником збільшення гіпофізом секреції ТТГ. Це вмикає адаптаційні механізми, спрямовані на вловлювання йоду, що циркулює у крові, накопичення синтезованих тиреоїдних гормонів, їх раціональне та ефективне використання [23]. Водночас кількість реутилізованого йоду $\epsilon$ недостатньою для йодування всього тиреоглобуліну, який накопичено в Щ3, а компенсаторно-пристосувальні процеси полягають в інтенсифікації інтратиреоїдного плину крові з подальшим збільшенням елімінації йоду із сироватки крові та активізації синтезу та секреції трийодтироніну (ТЗ). Тривале функціональне напруження Щ3, яке спостерігається у випадках незначного (менше ніж 20 мкг/добу) надходження йоду в організм, призводить до гіперплазії паренхіми органа. Одним із механізмів підтримання достатнього рівня синтезу тиреоїдних гормонів та збільшення ефективності їхньої утилізації $\epsilon$ прискорення перебігу тиреоїдного метаболізму. Це досягається шляхом збільшення вмісту монойодтироніну (МЙт) при одночасному зменшенні кількості дийодтироніну (ДЙТ), що зумовлює збільшення кількості йодованих тирозинів і зменшення енерговитрат на йодування. Водночас, хоча $\mathrm{T}_{3}$, продукція якого значно зростає, характеризується у 3-8 разів більшою гормональною активністю і більшим метаболічним ефектом, ніж тироксин $\left(\mathrm{T}_{4}\right)$, в багатьох органах і системах, внаслідок порушення значної кількості метаболічних процесів, відбуваються дисфункціональні зміни. Якщо рівновагу не буде своєчасно відновлено, вони можуть призвести до вичерпання резервних можливостей організму і розвитку тяжких органічних порушень [24].

Ситуації, при яких в організм надходить надлишкова кількість йоду, в природних умовах трапляються нечасто. До цього може призводити нераціональне, неадекватне щодо потреб організму споживання йодованих продуктів, комплексних полівітамінних препаратів, збагачених йодом харчових додатків, деяких йодовмісних лікарських речовин. Нетривале надходження в організм надлишкового йоду супроводжується пропорційним збільшенням активності тироцитів щодо захоплення ними йодиду, посиленням його органіфікації, синтезу та секреції тиреоїдних гормонів і ТТГ гіпофіза при одночасному збільшенні вмісту тиреоглобуліну та зменшенні кількості вільного $\mathrm{T}_{4}$ у сироватці крові. Після досягнення стану «насичення» ЩЗ йодом рівень його поглинання залозою зменшується. Тривале перебування організму в умовах йодного надлишку негативно позначається на продукуванні тиреоїдних гормонів, а отже і загальному стані організму [26, 31]. Спостерігається пригнічення деяких ферментних систем, зокрема тиреоїдних ферментів, які $\epsilon$ необхідними для гормонопоезу. Хронічне надлишкове надходження йоду в організм призводить до збільшення розмірів ЩЗ та розвитку явищ гіпотиреоїдизму.

Оскільки ЩЗ $є$ складною багаторівневою біологічною системою, що має механізми, які дають змогу нівелювати негативні наслідки впливу надлишкової кількості йоду, концентрація тиреоїдних гормонів у сироватці крові певний час залишається в межах, які дозволяють підтримувати гомеостаз і забезпечувати нормальний перебіг метаболічних процесів. Про це свідчить той факт, що при надходженні в організм масивних доз йоду вміст загального і вільного $\mathrm{T}_{4}$ зменшується, проте рівень $\mathrm{T}_{3}$ тривалий час залишається незмінним. Хоча надлишкове надходження йоду в організм супроводжується підвищенням рівня ТТГ, на початкових етапах спостерігається пригнічення функції Щз. Цей феномен отримав назву ефекту Вольфа-Чайкова. У клінічній практиці його використовують для пригнічення функції органа i зменшення таким чином явищ гіпертиреозу. Після відміни масивних доз йоду діяльність Щз швидко нормалізується [15]. 
Огляди літератури, оригінальні дослідження, погляд на проблему, ювілеї

Висновки. 1. Складний ембріогенез щ3, значна варіабельність макроморфологічних типів, рясна васкуляризація, особливості вегетативної іннервації, наявність у паренхімі органа, поряд із тироцитами, їх клітин-антагоністів, клітин-продуцентів інших біологічно активних речовин та клітин, які беруть участь у імунних процесах, створюють морфологічні передумови для появи і розвитку девіацій у її діяльності.

2. Регулювання функції ЩЗ здійснюється розгалуженою системою екстратиреоїдних та інтратиреоїдних зв'язків, з яких найбільше значення мають зв'язки гіпоталамо-гіпофізарної, вегетативної нервової та імунної систем, діяльність С-клітин, концентрація іонів йоду та кальцію в сироватці крові. Така складна система контролю, попри свою поліваріантність, може бути вразли-

вою у разі появи відхилень і порушень у діяльності органа.

3. Вплив регулювальної системи гіпоталамусгіпофіз на щитоподібну залозу відбувається залежно від кількості йоду, що надходить до організму. Споживання незначних доз йоду супроводжується зміною низки функціональних констант, зокрема інтратиреоїдних співвідношень МЙт/ДЙт, ДЙт/T $T_{4} T_{3} / T_{4}$. У випадках вираженого дефіциту йоду в тканинах зростає швидкість трансформації $\mathrm{T}_{4}$ в $\mathrm{T}_{3}$ та значно зменшується рівень $\mathrm{T}_{4}$ при нормальному або збільшеному вмісті $\mathrm{T}_{3}$, що становить небезпеку вичерпання адаптаційних резервів організму. Тривале споживання збільшеної кількості йоду і зумовлене цим підвищення рівня ТТГ порушує координування діяльності ЩЗ і функціонально пов'язаних з нею органів.

\section{ЛІТЕРАТУРА}

1. Алешин Б. В. Гипоталамус и щитовидная железа / Б. В. Алешин. - М. : Медицина, 1983. - 184 с.

2. Бизунок Т. А. Роль нейромедиаторов в регуляции функции щитовидной железы / Т. А. Бизунок, Н. А. Бизунок // Медицинский журнал. - 2006. - № 2.- С. 10-12.

3. Ветшев П. С. Прогностические факторы хирургического лечения диффузного токсического зоба /П. С. Ветшев, С. К. Мамаева // Хирургия. Журнал имени Н. И. Пирогова. - 2006. - № 2. - С. 63-68.

4. Герасименко В. Л. Морфологические особенности щитовидной железы у больных диффузным токсическим зобом / В. Л. Герасименко // Экспериментальная и клиническая медицина. - 2001. - № 1. - С. 43-44.

5. Герасименко В. Л. Оптимізація хірургічного лікування дифузного токсичного зоба на підставі морфодіагностичних критеріїв : автореф. дис. на здобуття вченого ступеня канд. мед. наук : спец. 14.01.03 "Хірургія" / В. Л. Герасименко. - Тернопіль : ТДМУ, 2004. - 19 с.

6. Звіт "Про національне дослідження вживання населенням харчових мікронутрієнтів". Україна. 2003 рік / В. І. Кравченко, А. Н. Каракашян, І. П. Луб'янова, І. В. Калачова // Главный врач. - 2007. - № 5. - С. 106-109.

7. Лукша Л. С. Сократительные и эндотелийзависимые дилаторные реакции аорты при гипертиреозе / Л. С. Лукша, И. М. Багель, Л. М. Лобанок // Проблемы эндокринологии. - 2000. - № 6. - С. 38-41.

8. Маменко М. Є. Йодний дефіцит та йододефіцитні захворювання (лекція) / М. Є. Маменко // Перинатология и педиатрия. - 2013. - № 1(53). - С. 97-105.

9. Морфофункциональная характеристика восстановительных процессов в резецированной щитовидной железе крыс / В. А. Глумова, Г. В. Черных, Н. М. Петров [и др.] // Бюллетень экспериментальной биологии и медицины. - 1985. - № 6. - С.740-744.

10. Морфофункціональні особливості та поляризаційні властивості тканини щитоподібної залози інтакт-

них щурів / Т. М. Бойчук, А. А. Ходоровська, Н. П. Пентелейчук, С. Б. Єрмоленко // Буковинський медичний вісник. - 2012. - Т. 16, № 3 (63), ч. 1. - С. 13-15.

11. Нікітіна О. В. Стан деяких компонентів інтерстиціального простору щитовидної залози людини у нормі та при патології / О. В. Нікітіна // Медичні перспективи. 2000. - Т. 5, № 2. - С. 10-13.

12. Олейник В. А. Гиперплазия щитовидной железы - норма или патология? / В. А. Олейник, Е. А. Беникова // Пробл. эндокринологии. - 1992. - Т. 38, № 4. - С. 13-14.

13. Оперативная хирургия / под общ. ред. проф. И. Литтманна; пер. с венг. М. Алекса, М. Н. Аничков, Б. Сегаль, М. Сиза, А. Шош. - Будапешт : Издательство Академии Наук Венгрии, 1982. - С. 37-46. - ISBN 963-05-3051-1

14. Приступюк О. М. Дифузний нетоксичний зоб: класифікація, діагностика, профілактика та лікування / О. М. Приступюк, І. Абу Аяш, О. Я. Гирявенко // Клінічна ендокринологія та ендокринна хірургія. - 2007. - № 3. С. 3-13.

15. Рак щитовидной железы. Эпидемиологические, радиобиологические и иммуноэндокринологические аспекты с обоснованием иммунотерапии : монография / Ю. А. Гриневич, А. Е. Присяжнюк, В. С. Процык [и др.] ; под ред. Ю. А. Гриневича, А. А. Чумака. - К. : Здоров'я, 2011. -208 c.

16. Ром-Богуславская Е. С. Гистамин и щитовидная железа / Е. С. Ром-Богуславская // Патологическая физиология и экспериментальная терапия. - 1984. - № 6. С. 79-82.

17. Рябуха О. І. Спосіб лікування та запобігання ендемічному зобу : патент № 99116037, Україна (Заявл. 03.11.1999; Опубл. 16.04.2001) / О. І. Рябуха // Промислова власність. Офіційний бюлетень. - 2001. - № 3, Ч. ІІ. C. 1-53.

18. Севрюкова О. И. В-клетки щитовидной железы / О. И. Севрюкова, В. С. Боташева // Вестник Ставрополь- 
Огляди літератури, оригінальні дослідження, погляд на проблему, ювілеї

ского государственного университета. - 2011. - № 74. C. 59-62.

19. Сиднева Л. Н. Изменение концентрации катехоламинов в зависимости от уровня тиреоидных гормонов в организме / Л. Н. Сиднева, Е. И. Адамская // Проблемы эндокринологии. - 1975. - № 6. - С. 84-87.

20. Теппермен Дж. Физиология обмена веществ и эндокринной системы / Дж. Теппермен, Х. Теппермен; пер. с англ. - М. : Мир, 1989. - 656 с. - ISBN 5-03-000548-X.

21. Хаустов С. О. Патофізіологія теплового балансу щитоподібної залози при синдромі гіпер-, гіпо-, еутиреозу : автореф. дис. на здобуття вченого ступеня канд. мед. наук : спец. 14.03.04 "Патологічна фізіологія" / С. О. Хаустов. - Одеса : ОНМедУ, 2004. - 19 с.

22. Шеститко И. И. Ацетилхолинэстераза щитовидной железы при тиреотоксикозе и зобной болезни / И. И. Шеститко // Проблемы эндокринологии. - 1982. № 4. - С. 17-20.

23. Шрейбер В. Патофизиология желез внутренней секреции / В. Шрейбер ; пер. с чеш. - Прага : Авиценум, 1987. -493 с.

24. Щитовидная железа. Фундаментальные аспекты / под ред. А. И. Кубарко, С. Ямасита. - Минск; Нагасаки : Омуро-Принт, 1998. - 368 с.

25. Ahrén B. Thyroid neuroendocrinology: neural regulation of thyroid hormone secretion / B. Ahrén // Endocrine Reviews. - 1986. - Vol. 7, Issue 2. - P. 149-155.

26. Clugston G. lodine-induced thyrotoxicosis / G. Clugston, M. Beaudry, F. Delange // The Lancet. - 1996. Vol. 347, Issue 9007. - P. 1051.

27. Chapter 21 SURGERY OF THE THYROID [Internet] / E. Kaplan, P. Angelos, M. Applewhite [et al.] // Endotext. - 2015; Last Update: Sept. 25. - Retrieved from: https://www.ncbi.nlm.nih.gov/books/NBK285564/

28. Early adaptation of thyrotropin and thyroglobulin secretion to experimentally decreased iodine supply in man / G. Brabant, P. Bergmann, C. M. Kirsch [et al.] // Metabolism. - 1992. - Vol. 41, Issue 10. - P. 1093-1096.

29. Estrogen promotes growth of human thyroid tumor cells by different molecular mechanisms / D. Manole, B. Schildknecht, B. Gosnell [et al.] // The Journal of Clinical Endocrinology \& Metabolism. - 2001. - Vol. 86, Issue 3. P. 1072-1077.

30. Induction of thyroid papillary carcinoma cell proliferation by estrogen is associated with an altered expression of Bcl-xL / M. L. Lee, G. G. Chen, A. C. Vlantis [et al.] // The Cancer Journal. - 2005. - Vol. 11, Issue 2. - P. 113-121.

31. lodine-induced thyrotoxicosis in Kivu, Zaire / P. P. Bourdoux, A. M. Ermans, A. Mukalay wa Mukalay [et al.] // The Lancet. - 1996. - Vol. 347, Issue 9000. - P. 552-553.

32. Khatawkar A. V. Thyroid gland - historical aspects, embryology, anatomy and physiology / A. V. Khatawkar, S. M. Awati // International Archives of Integrated Medicine. - 2015. - Vol. 2, Issue 9. - P. 165-171.

33. Maayan M. L. Dopamine and L-dopa: inhibition of thyrotropin-stimulated thyroidal thyroxine release / M. L. Ma- ayan, R. V. Sellitto, E. M. Volpert // Endocrinology. - 1986. Vol. 118, Issue 2. - P. 632-636.

34. Melander A. Aminergic regulation of thyroid activity: importance of the sympathetic innervation and of the mast cells of the thyroid gland / A. Melander // Acta Medica Scandinavica. - 1977. - Vol. 201, Issue 4. - P. 257-262.

35. Mölne J. Adherence of Rfd-1 positive dendritic cells to the basal surface of thyroid follicular cells in Graves' disease / J. Mölne, S. Jansson, L. E. Ericson, M. Nilsson // Autoimmunity. - 1994. - Vol. 17, Issue 1. - P. 59-71.

36. Nakabayashi K. Activation of the luteinizing hormone receptor following substitution of Ser-277 with selective hydrophobic residues in the ectodomain hinge region / K. Nakabayashi, M. Kudo, B. Kobilka, A. J. Hsueh // The Journal of Biological Chemistry. - 2000. - Vol. 275, No. 39. P. 30264-30271.

37. Ontogeny, anatomy, metabolism and physiology of the thyroid [Internet] / C. Maenhaut, D. Christophe, G. Vassart [et al.] // Endotext. - 2015; Last Update: Jul. 15. - Retrieved from: https://www.ncbi.nlm.nih.gov/books/NBK285554/

38. PAX8, TITF1, and FOXE1 gene expression patterns during human development: new insights into human thyroid development and thyroid dysgenesis-associated malformations / S. S. Trueba, J Augé, G. Mattei [et al.] // The Journal of Clinical Endocrinology \& Metabolism. - 2005. Vol. 90, Issue 1. - P. 455-462.

39. Pituitary-thyroid setpoint and thyrotropin receptor expression in consomic rats / L. C. Moeller, M. Alonso, X. Liao [et al.] // Endocrinology. - 2007. - Vol. 148, Issue 0. P. 4727-4733.

40. Santisteban P. Development and anatomy of the hypothalamic-pituitary-thyroid axis / P. Santisteban // Werner and Ingbar's the thyroid a fundamental and clinical text; L. E. Braverman, R. D. Utiger (Eds.). - Philadelphia, PA : Lippincott Williams \& Wilkins, 2005. - P. 8-25.

41. The primate thyroid gland contains receptors for androgens / P. J. Sheridan, H. C. Jr. McGill, J. C. Lissitzky, P. M. Martin // Endocrinology. - 1984. - Vol. 15, Issue 6. P. 2154-2159.

42. Singhal R. L. Brain biogenic amines and altered thyroid function / R. L. Singhal, R. B. Rastogi, P. D. Hrdina // Life Sciences. - 1975. - Vol. 17, Issue 11. - P. 1617-1626.

43. Stathatos N. Anatomy and physiology of the thyroid gland: clinical correlates to thyroid cancer / N. Stathatos // Thyroid Cancer; L. Wartofsky, D. Van Nostrand (Eds.). - New York, NY: Springer, 2016. - P. 3-8.

44. Van Keymeulen A. TSH induces insulin receptors that mediate insulin costimulation of growth in normal human thyroid cells / A. Van Keymeulen, J. E. Dumont, P. P. Roger // Biochemical and Biophysical Research Communications. - 2000. - Vol. 279, Issue 1, P. 202-207.

45. Young J. B. Sympathetic nervous system activity in rat thyroid: potential role in goitrogenesis / J. B. Young, M. E. Burgi-Saville, U. Burgi, L. Landsberg // American Journal of Physiology-Endocrinology and Metabolism. - 2005. Vol. 288, Issue 5. - P. E861-E867. 
Огляди літератури, оригінальні дослідження, погляд на проблему, ювілеї

\section{REFERENCES}

1. Aleshin, B.V., \& Gubskiy, V.I. (1983). Gipotalamus i shchitovidnaya zheleza [Hypothalamus and thyroid]. Moscow: Meditsina [in Russian].

2. Bizunok, T.A., \& Bizunok, N.A. (2006). Rol neyromediatorov $v$ regulyatsii funktsii shchitovidnoy zhelezy [The role of neurotransmitters in the regulation of thyroid function]. Meditsinskiy zhurnal - Medical Journal, 2, 10-12 [in Russian].

3. Vetshev, P.S., \& Mamayeva, S.K. (2006). Prognosticheskiye faktory khirurgicheskogo lecheniya diffuznogo toksicheskogo zoba [Prognostic factors of surgical treatment of diffuse toxic goiter]. Khirurgiya. Zhurnal imeni N.I. Pirogova - Journal Surgery named after N.I. Pirogov, 2, 63-68 [in Russian].

4. Gerasimenko, V.L. (2001). Morfologicheskiye osobennosti shchitovidnoy zhelezy u bolnykh diffuznym toksicheskim [Morphological features of the thyroid gland in patients with diffuse toxic goiter]. Eksperimentalnaya i klinicheskaya meditsina - Experimental and Clinical Medicine, 1, 43-44 [in Russian].

5. Gerasimenko, V.L. (2001). Optymizatsiia khirurhichnoho likuvannia dyfuznoho toksychnoho zoba na pidstavi morfodiahnostychnykh kryteriiv [Optimization of surgical treatment of diffuse toxic goiter on the basis of morphodiagnostic criteria]. Extended abstract of Candidate's thesis. Ternopil: TSMU [in Ukrainian].

6. Kravchenko, V.I., Karakashyan, A.N., Lub'yanova, I.P., \& Kalachova, I.V. (2007). Zvit Pro natsionalne doslidzhennia vzhyvannia naselenniam kharchovykh mikronutriientiv. Ukraina. 2003 rik [About the National Study on the Consumption of Food Micronutrients: A Report. Ukraine. 2003]. Glavnyy vrach - Head Physician, 5, 106-109 [in Ukrainian].

7. Luksha, L.S., Bagel, I.M., \& Lobanok, L.M. (2000) Sokratitelnyye i endoteliyzavisimyye dilatatornyye reaktsii aorty pri gipertireoze [Contractile and endotheliumdependent dilatatory reactions of the aorta in hyperthyrosis]. Problemy endokrinologii-Problems of Endocrinology, 6, 38-41 [in Russian].

8. Mamenko, M.Ye. (2013). Yodnyi defitsyt ta yododefitsytni zakhvoriuvannia (lektsiia) [lodine deficiency and iodine deficiency disorders-A lecture notes]. Perinatologiya i pediatriya - Peri i Pediatriya, 1(53), 97-105 [in Ukrainian].

9. Glumova, V.A., Chernykh, G.V., Petrov, N.M., Semenov, V.V., Kuznetsova, V.M., \& Glumov, V.Ya. (1985). Morfofunktsionalnaya kharakteristika vosstanovitelnykh protsessov v rezetsirovannoy shchitovidnoy zheleze krys [Morphofunctional characteristics of the recovery processes in the rat resected thyroid]. Byulleten eksperimentalnoy biologii i meditsiny - Bulletin of Experimental Biology and Medicine, 6, 740-744 [in Russian].

10. Boichuk, T.M., Khodorovska, A.A., Penteleichuk, N.P., \& Yermolenko, S.B. (2012). Morfofunktsionalni osoblyvosti ta poliaryzatsiini vlastyvosti tkanyny shchytopodibnoi zalozy intaktnykh shchuriv [Morphofunctional features and polarization properties of the thyroid tissue of intact rats]. Bukovynskyi medychnyi visnyk - BMH Journal, 16, 3(63)/1, 13-15 [in Ukrainian].

11. Nikitina, O.V. (2000). Stan deiakykh komponentiv interstytsialnoho prostoru shchytovydnoi zalozy liudyny u normi ta pry patolohii [The state of some components of the interstitial space of the human thyroid in normal and in pathology]. Medychni perspektyvy - Medical Perspectives, 5, 2, 10-13 [in Ukrainian].

12. Oleynik, V.A., \& Benikova, E.A. (1992). Giperplaziya shchitovidnoy zhelezy - norma ili patologiya? [Hyperplasia of the thyroid gland is normal or pathological?]. Problemy endokrinologii-Problems of Endocrinology, 38, 4, 13-14 [in Russian].

13. Littmann, I. (Ed.). (1982). Operativnaya khirurgiya [Operative surgery]. (M. Alexa, M.N. Anichkov, B. Segal, M. Siza, A. Shosh, Trans from Hungarian). Budapest: Akadémiai Kiadó. ISBN 963-05-3051-1 [in Russian].

14. Pristupyuk, A., Abu Ayash, I., \& Giryavenko, H. (2007). Dyfuznyi netoksychnyi zob: klasyfikatsiia, diahnostyka, profilaktyka ta likuvannia [Diffuse non toxic goiter: classification, diagnosis, prophylaxis and treatment]. Klinichna endokrynolohiia ta endokrynna khirurhiia-Clinical Endocrinology and Endocrine Surgery, 3, 3-13 [in Ukrainian].

15. Grinevich, Yu.A., \& Chumak, A.A. (Eds.). (2011). Rak shchitovidnoy zhelezy. Epidemiologicheskiye radiobiologicheskiye i immunoendokrinologicheskiye aspekty s obosnovaniyem immunoterapii: monografiya [Thyroid cancer. Epidemiological, radiobiological andimmunoendocrinological aspects with the evidences of immunotherapy: monograph]. Kiev: Zdorovia [in Russian].

16. Rom-Boguslavskaya, E.S. (1984). Gistamin i shchitovidnaya zheleza [Histamine and thyroid]. Patologicheskaya fiziologiya i eksperimental'naya terapiya-Pathological Physiology and Experimental Therapy, 6, 79-82 [in Russian].

17. Ryabukha, O.I. (2001). Sposib likuvannia ta zapobihannia endemichnomu zobu: patent № 99116037, Ukraina (Zaiavl. 03.11.1999; Opubl. 16.04.2001). [Method of treatment and prevention of endemic goiter: Patent No 99116037 , Ukraine. (Declared 03.11.1999; Published 16.04.2001)]. Promyslova vlasnist. Ofitsiinyi biuleten - Industrial property. Official Bulletin, 3/2, 1.53. [in Ukrainian].

18. Sevryukova, O.I., \& Botasheva, V.S. (2011). B-kletki shchitovidnoy zhelezy [Thyroid gland B-cells]. Vestnik Stavropolskogo gosudarstvennogo universiteta - Vestnik of Stavropol State University, 74, 59-62 [in Russian].

19. Sidneva, L.N., \& Adamskaya, E.I. (1975). Izmeneniye kontsentratsii katekholaminov $v$ zavisimosti ot urovnya tireoidnykh gormonov v organizme [Changes in the catecholamine concentration in the hypothalamus depending on the thyroid hormone level in the organism]. Problemy endokrinologii - Problems of Endocrinology, 6, 84-87 [in Russian].

20. Tepperman, J, \& Tepperman, H.M. (1989). Fiziologiya obmena veshchestv $i$ endokrinnoy sistemy [Metabolic and endocrine physiology]. Moscow: Mir [in Russian].

21. Khaustov S.O. (2004). Patofiziolohiia teplovoho balansu shchytopodibnoi zalozy pry syndromi hiper-, hipo-, eutyreozu [Pathophysiology of the thermal balance of the thyroid gland in hyper-, hypo-, euthyroid syndrome]. Extended abstract of Candidate's thesis. Odesa: ONMedU [in Ukrainian].

22. Shestitko, I.I. (1982). Atsetilkholinesteraza shchitovidnoy zhelezy pri tireotoksikoze i zobnoy bolezni [Thyroid acetylcholinesterase in thyrotoxicosis and goiter]. Problemy endokrinologii - Problems of Endocrinology, 4, 17-20 [in Russian].

23. Schreiber, V. (1987). Patofiziologiya zhelez vnutrenney sekretsii [Patofysiologie žláz s vnitřní sekrecí]. (Trans from Czech). Praha: Avicenum [in Russian]. 
Огляди літератури, оригінальні дослідження, погляд на проблему, ювілеї

24. Kubarko, A.I., \& Yamashita, S. (Eds.). (1998). Shchitovidnaya zheleza. Fundamentalnyye aspekty [Thyroid. Fundamental Aspects]. Minsk; Nagasaki: Omuro-Print [in Russian].

25. Ahrén, B. (1986). Thyroid neuroendocrinology: neural regulation of thyroid hormone secretion. Endocrine Reviews, 7, 2, 149-155.

26. Clugston, G., Beaudry, M., \& Delange, F. (1996). Clugston G. Iodine-induced thyrotoxicosis. The Lancet, 347, 9007, 1051.

27. Kaplan, E., Angelos, P., Applewhite, M., Mercier, F., \& Grogan, R.H. (2015). Chapter 21 SURGERY OF THE THYROID [Internet]. Endotext [Last Update: 2015, Sept. 25]. Retrieved from: https://www.ncbi.nlm.nih.gov/books/NBK285564/

28. Brabant, G., Bergmann, P., Kirsch, C.M., Köhrle, J., Hesch, R.D., \& von zur Mühlen, A. (1992). Early adaptation of thyrotropin and thyroglobulin secretion to experimentally decreased iodine supply in man. Metabolism, 41, 10, 1093-1096.

29. Manole, D., Schildknecht, B., Gosnell, B., Adams, E., \& Derwahl, M. (2001). Estrogen promotes growth of human thyroid tumor cells by different molecular mechanisms. The Journal of Clinical Endocrinology \& Metabolism, 86, 3, 1072-1077.

30. Lee, M.L, Chen, G.G, Vlantis, A.C, Tse, G.M, Leung, B.C, $\&$ van Hasselt, C.A. (2005). Induction of thyroid papillary carcinoma cell proliferation by estrogen is associated with an altered expression of Bcl-xL. The Cancer Journal, 11, 2, 113-121.

31. Bourdoux, P.P., Ermans, A.M., Mukalay wa Mukalay, A., Filetti, S., \& Vigneri, R. (1996). lodine-induced thyrotoxicosis in Kivu, Zaire. The Lancet, 347, 9000, 552-553.

32. Khatawkar, A.V., \& Awati, S.M. (2015). Thyroid glandhistorical aspects, embryology, anatomy and physiology. International Archives of Integrated Medicine, 2, 9, 165-171.

33. Maayan, M.L., Sellitto, R.V., \& Volpert, E.M. (1986). Dopamine and L-dopa: inhibition of thyrotropin-stimulated thyroidal thyroxine release. Endocrinology, 118, 2, 632-636.

34. Melander, A. Aminergic regulation of thyroid activity: importance of the sympathetic innervation and of the mast cells of the thyroid gland. Acta Medica Scandinavica, 201, 4, 257-262.

35. Mölne, J., Jansson, S., Ericson, L.E., \& Nilsson, M. (1994). Adherence of Rfd-1 positive dendritic cells to the basal surface of thyroid follicular cells in Graves' disease. Autoimmunity, 17, 1, 59-71.

36. Nakabayashi, K., Kudo, M., Kobilka, B., \& Hsueh, A.J. (2000). Activation of the luteinizing hormone receptor following substitution of Ser-277 with selective hydrophobic residues in the ectodomain hinge region. The Journal of Biological Chemistry, 275, 39, 30264-30271.

37. Maenhaut, C., Christophe, D., Vassart, G., Dumont, J., Roger, P.P., \& Opitz, R. (2015). Ontogeny, anatomy, metabolism and physiology of the thyroid [Internet]. Endotext [Last Update: 2015, Jul. 15]. Retrieved from: https: //www. ncbi.nlm.nih.gov/books/NBK285554/

38. Trueba, S.S., Augé, J., Mattei, G., Etchevers, H., Martinovic, J., Czernichow, P., ... Attié-Bitach, T. (2005). PAX8, TITF , and FOXE 1 gene expression patterns during human development: new insights into human thyroid development and thyroid dysgenesis-associated malformations. The Journal of Clinical Endocrinology \& Metabolism, $90,1,455-462$.

39. Moeller, L.C, Alonso, M., Liao, X., Broach, V., Dumitrescu, A., Van Sande, J., ... Weiss, R.E. (2007). Pituitarythyroid setpoint and thyrotropin receptor expression in consomic rats. Endocrinology, 148, 10, 4727-4733.

40. Santisteban, P. (2005). Development and anatomy of the hypothalamic-pituitary-thyroid axis. In L. E. Braverman, R. D. Utiger (Eds.). Werner and Ingbar's the thyroid a fundamental and clinical text (pp. 8-25). Philadelphia, PA: Lippincott Williams \& Wilkins.

41. Sheridan, P.J., McGill, H.C.Jr., Lissitzky, J.C., \& Martin, P.M. (1984). The primate thyroid gland contains receptors for androgens. Endocrinology, 115, 6, 2154-2159.

42. Singhal, R.L., Rastogi, R.B., \& Hrdina, P.D. (1975). Brain biogenic amines and altered thyroid function. Life Sciences, 17, 11, 1617-1626.

43. Stathatos, N. (2016). Anatomy and Physiology of the Thyroid Gland: Clinical Correlates to Thyroid Cancer. In L. Wartofsky, D. Van Nostrand (Eds.). Thyroid Cancer (pp. 3-8). New York, NY: Springer.

44. Van Keymeulen, A., Dumont, J.E., \& Roger, P.P. (2000). TSH induces insulin receptors that mediate insulin costimulation of growth in normal human thyroid cells. Biochemical and Biophysical Research Communications, $279,1,202-207$.

45. Young, J.B., Burgi-Saville, M.E., Burgi, U., \& Landsberg L. (2005). Sympathetic nervous system activity in rat thyroid: potential role in goitrogenesis. American Journal of Physiology-Endocrinology and Metabolism, 288, 5, E861-E867.

\section{TO THE STRUCTURAL AND FUNCTIONAL PRECONDITIONS OF THE EMERGENCE OF THYROID PATHOLOGY (LITERATURE REVIEW)}

\section{Lviv Medical Institute}

○O. I. Ryabukha

SUMMARY. Significant distribution and social significance of thyroid pathology actualize the in-depth elucidation of the basic preconditions for its occurrence.

The aim of the work - to analyze and generalize those features of the structure and functional activity of the thyroid gland, which may be the prerequisites for its pathology. It is found that conditionally such preconditions can be divided into structural and functional. The complicated embryogenesis of the thyroid gland, the considerable variability of its macromorphological types, abundant vascularization and the peculiarities of autonomic innervation of the organ, the presence in its parenchyma, along with thyrocytes of their antagonistic cells, and also the cells producing other biologically active substances and cells that take part in the immune processes, are the main morphological preconditions 
Огляди літератури, оригінальні дослідження, погляд на проблему, ювілеї

for the emergence and development of deviations in its activity. However, the regulation of the function of the thyroid is carried out by the branched system of extrathyroid and intrathyroid mechanisms, of which the most important are the connections of the nervous system, in particular, the autonomic, and immune system, the activity of para follicular cells, the concentration of iodine and calcium ions in the blood serum. Such a complex control system, in spite of its multivariation, may be vulnerable in case of changes in the conditions of existence, deviations or violations in the activities of the organism. The influence of the hypothalamic-pituitary-regulating system on the thyroid gland occurs depending on the amount of iodine entering the body. The consumption of small doses of iodine is accompanied by a change in a number of functional constants, in particular, the intra-thyroid relationship between monoiodothyrozine and diiodothyrosine, diiodothyrosine and thyroxine, triiodothyrosine and thyroxine; in cases of severe deficiency of iodine, the rate of transformation of $T_{4}$ in $T_{3}$ in tissues increases and the level of $T_{4}$ significantly decreases with normal or increased $T_{3}$ content, which poses a danger of the exhaustion of the adaptive reserves of the organism. Prolonged consumption of an increased amount of iodine and the resulting increase in TSH level violates the coordination of the activity of the thyroid gland and functionally related organs.

KEY WORDS: thyroid gland; peculiarities of the structure; peculiarities of functioning.

\section{К СТРУКТУРНЫМ И ФУНКЦИОНАЛЬНЫМ ПРЕДПОСЫЛКАМ ВОЗНИКНОВЕНИЯ ТИРЕОИДНОЙ ПАТОЛОГИИ (ОБЗОР ЛИТЕРАТУРЫ)}

๑о. И. Рябуха

\section{Львовский медицинский институт}

РЕЗЮМЕ. Значительное распространение и социальное значение тиреоидной патологии актуализируют потребность в углублённом установлении основных предпосылок её возникновения.

Целью работы были анализ и обобщение особенностей строения и деятельности щитовидной железы, которые могут быть предпосылками возникновения её патологии. Выяснено, что такие предпосылки условно можно разделить на структурные и функциональные. Сложный эмбриогенез щитовидной железы, значительная вариабельность её макроморфологических типов, обильная васкуляризация и особенности вегетативной иннервации, наличие в паренхиме органа, наряду с тироцитами, их клеток-антагонистов, а также клеток-продуцентов других биологически активных веществ и клеток, участвующих в иммунных процессах, являются основными морфологическими предпосылками появления и развития девиаций в деятельности железы. Вместе с тем, регулирование функции щитовидной железы осуществляется разветвлённой системой екстратиреоидных и интратиреоидных механизмов, из которых наибольшее значение имеют связи нервной, в частности вегетативной, и иммунной систем, деятельность С-клеток, концентрация ионов йода и кальция в сыворотке крови. Такая сложная система контроля, несмотря на свою поливариантность, может быть уязвимой в случае изменения условий существования, отклонений или нарушений в деятельности органа. Влияние регулирующей системы гипоталамус-гипофиз на щитовидную железу происходит в зависимости от количества йода, поступающего в организм. Потребление незначительных доз йода сопровождается изменением ряда функциональных констант, в частности, интратиреоидных соотношений между монойодтирозином и дийодтирозином, дийодтирозином и тироксином, трийодтирозином и тироксином; в случае выраженного дефицита йода в тканях возрастает скорость трансформации $\mathrm{T}_{4}$ в $\mathrm{T}_{3}$ и значительно уменьшается уровень $T_{4}$ при нормальном или увеличенном содержании $\mathrm{T}_{3}$, что представляет опасность исчерпания адаптационных резервов организма. Длительное потребление увеличенного количества йода и обусловленное этим повышение уровня ТТГ нарушает координирование деятельности щитовидной железы и функционально связанных с нею органов.

КЛЮЧЕВЫЕ СЛОВА: щитовидная железа; особенности строения; особенности функционирования.

Отримано 21.02.2018 